\title{
A COMERCIALIZAÇÃO DE PRODUTOS DO AGROEXTRATIVISMO EM FEIRAS LIVRES DO ALTO JEQUITINHONHA
}

\section{THE COMMERCIALIZACION OF AGROEXTRATIVISM PRODUCTS IN MUNICIPAL MARKETS OF THE ALTO JEQUITINHONHA}

\begin{abstract}
Danilo Marinho Lamêgo Borges
Mestrado em Sociedade, Ambiente e Território - Universidade Federal de Minas Gerais e Universidade Estadual de Montes Claros, Montes Claros, MG, Brasil danilo.marinho.borges@gmail.com

Vanessa Marzano Araújo Instituto de Ciências Agrárias da Universidade Federal de Minas Gerais, Montes Claros, MG, Brasil vanessamarzano@yahoo.com.br

Eduardo Magalhães Ribeiro Instituto de Ciências Agrárias da Universidade Federal de Minas Gerais, Montes Claros, MG, Brasil eduardomr@pq.cnpq.br

Maria Sirlene da Cruz

Mestrado em Sociedade, Ambiente e Território - Universidade Federal de Minas Gerais e Universidade Estadual de Montes Claros, Montes Claros, MG, Brasil sirlenecruz.mg@gmail.com

Lucas Rocha Santos Instituto de Ciências Agrárias da Universidade Federal de Minas Gerais, Montes Claros, MG Brasil lucasrochalrs95@hotmail.com
\end{abstract}

\begin{abstract}
Resumo
O conhecimento de agricultores familiares tradicionais sobre a natureza permite que identifiquem, classifiquem e utilizem espécies vegetais. Assim, criam culturas alimentares específicas, territorializadas e, às vezes, sustentáveis, reunindo produção e cultura, sustento alimentar e geração de renda. Este artigo analisa a comercialização de produtos da natureza por agricultores do Alto Jequitinhonha. Entrevistando agricultoresfeirantes de cinco feiras livres municipais, a pesquisa que deu base ao artigo investigou quantidade, frequência e diversidade ofertados. O artigo revela que ocorre acentuada sazonalidade na oferta, que acompanha as safras; no entanto a grande diversidade da produção assegura que os agricultores vendam no correr de todo o ano.
\end{abstract}

Palavras-chave: Agroextrativismo. Vale do Jequitinhonha. Agricultura familiar. Comercialização. Circuitos curtos. 


\begin{abstract}
Traditional family farmers' knowledge of nature allows them to identify, classify, and use plant species. Thus, they create specific, territorialized, and, at times, sustainable food cultures, bringing together production and culture, food sustenance, and income generation. This article analyzes the commercialization of nature products by farmers from Alto Jequitinhonha. Interviewing farmers-marketers from five municipal fairs, the research that supported the article investigated the quantity, frequency, and diversity offered The article reveals that there is a strong seasonality in the supply, which accompanies the harvests; however, the great diversity of production ensures that farmers sell throughout the year.
\end{abstract}

Key words: Agroextractivism. Jequitinhonha valley. Family farming. Commercialization. Short circuits.

\title{
Introdução
}

A partir de meados do século XX ocorreu a disseminação da produção de alimentos em escala industrial, denominada como "fordismo alimentar". Em fins do mesmo século, num movimento aparentemente contraditório, cresceu a busca por alimentos saudáveis, produzidos nas proximidades do local de consumo, usando técnicas sustentáveis e identificados com a cultura alimentar do consumidor. Nesse cenário, os frutos nativos do cerrado se revelaram opção para alimentação saudável. Chegam à mesa dos consumidores urbanos graças à coleta feita por agricultores familiares, que muitas vezes vendem tais produtos junto com a produção agrícola. Frutos nativos, além de relevantes para alimentação de consumidores, sustentam famílias de agricultores, geram rendas e ocupações rurais na coleta, beneficiamento e vendas dos produtos.

A coleta e comercialização desses frutos é corriqueira no Alto Jequitinhonha. As famílias rurais têm costume de coletar frutos nativos do cerrado para consumir, processar e usar em trocas com as vizinhanças nas próprias comunidades. Mas, também os vendem, e no Jequitinhonha as feiras livres são os principais canais de escoamento. Feiras têm grande relevância para cultura, economia, soberania e segurança alimentar desse território. Nelas a agricultura familiar vende alimentos de qualidade para o abastecimento urbano, criando uma rica dinâmica de trocas entre as unidades domésticas rurais e as cidades, e assim se torna parte importante da economia dos pequenos municípios. 
A comercialização de produtos do agroextrativismo em feiras livres do Alto Jequitinhonha
Danilo Marinho Lamêgo Borges Vanessa Marzano Araújo

Eduardo Magalhães Ribeiro Maria Sirlene da Cruz Lucas Rocha Santos

Este artigo tem como objetivo analisar a comercialização de produtos da natureza por agricultores familiares em feiras do Alto Jequitinhonha, observando a relevância, a diversidade, o perfil do vendedor, as variações sazonais de oferta, origem e preços dos principais produtos vendidos. Para isso, acompanhou a presença de produtos do agroextrativismo nas feiras livres de cinco municípios por todos os meses entre dezembro de 2018 e dezembro 2019.

Nas partes seguintes, o artigo apresenta as técnicas usadas no estudo, em seguida revisa a literatura sobre frutos nativos, coleta, cerrado e feiras livres, para, finalmente, analisar o Alto Jequitinhonha e as peculiaridades da comercialização desses produtos.

\section{Metodologia}

Para realizar este estudo foram adotados dois procedimentos de pesquisa. Primeiro, foi feita revisão de literatura que procurou ser sistemática sobre o vale do Jequitinhonha: sua agricultura familiar, suas feiras e a relação entre agricultores e natureza. Para isso foi consultado um conjunto de obras, entre livros, artigos publicados em periódicos, dissertações de mestrado e relatórios técnicos. Destes últimos, dois estudos se destacaram pela afinidade com os propósitos deste artigo. Inicialmente, os estudos de Cruz (2019) e Cruz et al. (2019) sobre feiras livres do Alto Jequitinhonha forneceram bases para compreender a comercialização da agricultura familiar nas feiras livres. Em seguida, o relatório de Galizoni et al. (2019b) ofereceu informações minuciosas sobre a frequência da coleta e o consumo de produtos do agroextrativismo em comunidades rurais do município de Turmalina, no Alto Jequitinhonha. Esses estudos, que abordavam perspectivas diferentes dos mesmos sujeitos analisados neste artigo, foram essenciais para caracterizar os circuitos de comercialização e, principalmente, para entender os ritmos diferentes que existem entre coleta/consumo e vendas de frutos nativos: são duas dinâmicas que nem sempre se unem para abastecer os mercados locais, revelando que vendas em feiras refletem apenas parcialmente a intensidade do fluxo de coleta/consumo.

Segundo procedimento foi a pesquisa de campo, realizada em feiras livres de 5 municípios: Chapada do Norte, Itamarandiba, Minas Novas, Turmalina e Veredinha (Mapa 1). 


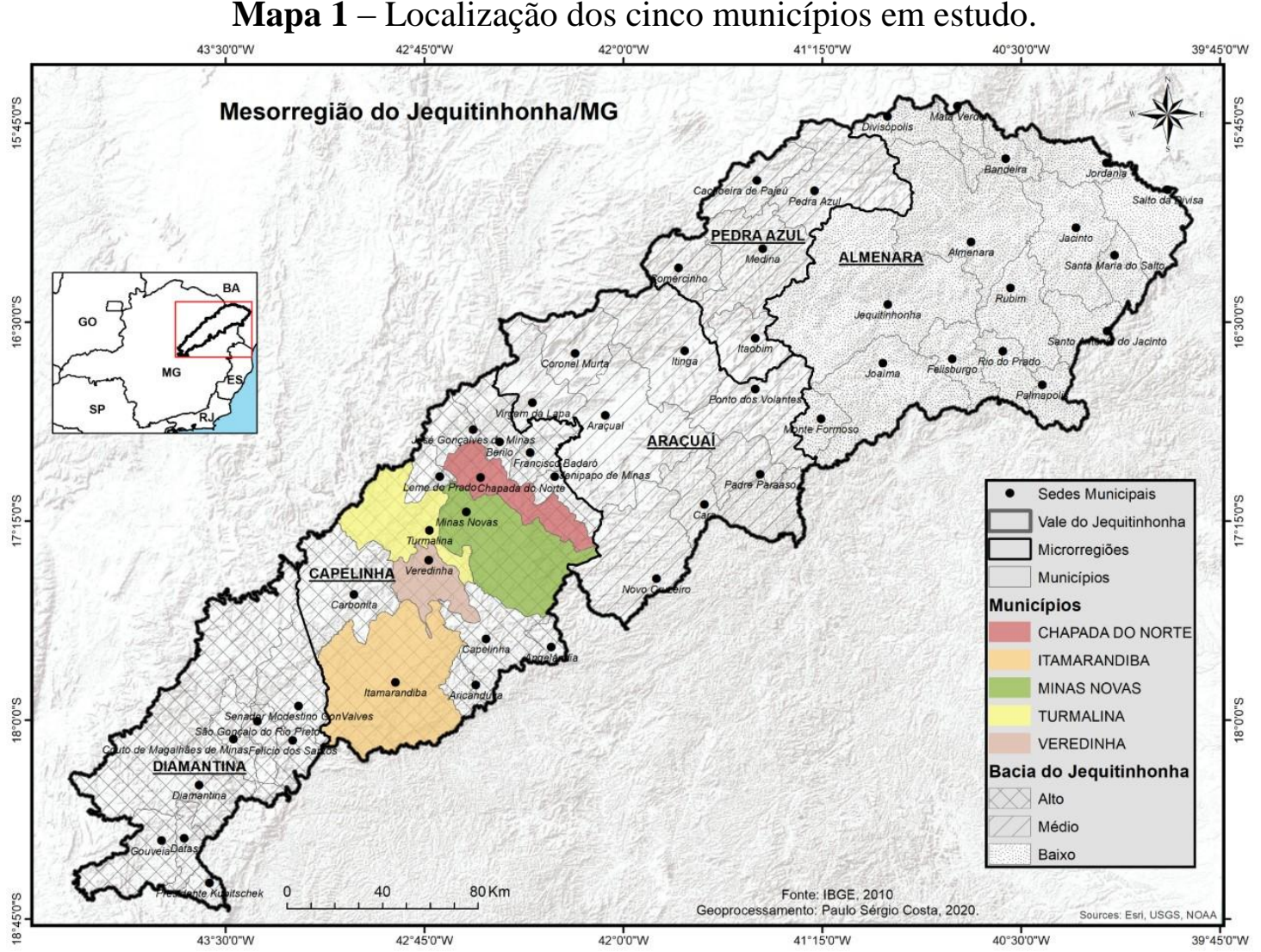

Fonte: IBGE (2010). Org.: Paulo Sérgio Costa, 2020.

Estes municípios fazem parte do Território do Alto Jequitinhonha, que foi delimitado pelo extinto Ministério do Desenvolvimento Agrário (BRASIL, 2005) e pelo governo de Minas Gerais (FJP, 2017) com o objetivo de orientar programas públicos. Os cinco municípios apresentam características semelhantes nos aspectos culturais, econômicos, fundiários e climáticos, e têm recebido desde os anos 1960 as mesmas políticas: os incentivos ao plantio de eucaliptos, as tomadas de terras comunais de lavradores, os planos de barragens para geração de energia e programas compensatórios de fabriquetas rurais (RIBEIRO, 2013). No entanto, mais que um passado conjunto de políticas "modernizadoras", os municípios têm em comum a sociedade de forte base rural, composta por agricultores familiares organizados em associações e sindicatos que, desde as lutas de posseiros conduzidas pelo legendário Vicente Nica nos anos finais da ditadura, participam ativamente da formulação de programas de desenvolvimento rural. A feira livre é uma, entre muitas, das ações construídas e sustentadas pela organização de agricultores familiares no Território; no entanto, se destaca por reunir campo e cidade em 
torno do consumo de alimentos e bens que trazem estampadas as marcas dessa cultura material específica (GALIZONI et al., 2019a).

Os municípios foram escolhidos em função da presença de organizações próprias de agricultores nas feiras: associações de feirantes, que se incumbiam de dialogar com órgãos públicos, programas institucionais de compras de excedentes, associações comunitárias e agências de desenvolvimento. A organização madura de feirantes permitia que os pesquisadores tivessem acesso a informantes qualificados, feirantes e líderes, que eram verdadeiros "especialistas" na atividade (MALINOVSKY \& DE LA FUENTE, 1957; BRANDÃO, 1986), e criava a oportunidade para os pesquisadores debater resultados de pesquisa com grupos que poderiam efetivamente empregá-los como insumos nas suas ações pelo melhoramento das feiras livres e do abastecimento urbano.

A pesquisa realizada nas feiras teve caráter exploratório. $\mathrm{O}$ objetivo principal foi descrever as características da população, do fenômeno e estabelecer as relações de causalidade entre as variáveis que estavam em cena, conforme Gil (2002). O método utilizado foi o estudo de caso, do tipo casos múltiplos, pois o foco era um objeto específico - a comercialização de frutos nativos na feira livre - que no entanto se espraiava por um conjunto amplo e minucioso de derivações, que compreendia a dinâmica própria da agricultura familiar, a sazonalidade da produção, a organização da cadeia produtiva, e as circunstâncias específicas de cada município; ou seja: o conjunto de implicações associadas à comercialização dos produtos nativos do cerrado. Conforme Yin (2001, p. 34), o estudo de caso pode ser aplicado para "descrever uma intervenção e o contexto na vida real em que ela ocorre"; neste caso, tanto a ação imediata (a feira) quanto o contexto (as relações direta e indiretamente derivadas) deveriam ser enfeixadas de modo a explicar a amplitude do fenômeno.

Assim, o levantamento do agroextrativismo compreendeu entrevistas com feirantes-agricultores-extrativistas, intermediários-vendedores e consumidores. Feiras livres são os principais canais de comercialização de produtos da agricultura familiar do Território; também, reúnem grande parte do escoamento dos frutos nativos do cerrado. Acontece que a produção desses frutos é espontânea, obedece ao ritmo da natureza e, na comercialização, se manifesta com forte sazonalidade: ao longo do ano, não apenas varia a quantidade ofertada de um mesmo produto, mas também a diversidade de produtos. 
A comercialização de produtos do agroextrativismo em feiras livres do Alto Jequitinhonha
Danilo Marinho Lamêgo Borges Vanessa Marzano Araújo

Eduardo Magalhães Ribeiro Maria Sirlene da Cruz Lucas Rocha Santos

Para conseguir perceber essas variações, os levantamentos de campo tiveram que ser realizados sistematicamente, todos os meses, em todas as feiras, entre dezembro de 2018 a dezembro de 2019, em levantamentos que mobilizavam pelo menos quatro pesquisadores a cada vez e, em termos locais, cobria "tempo das águas" e "tempo da seca", ou seja: todo um ciclo produtivo.

O levantamento, utilizando questionário estruturado, procurou captar diversidade e dimensões da oferta, preço, origem do vendedor e do produto. A interação dos pesquisadores com os informantes forneceu um conjunto de outras observações à margem que, quando pertinentes, foram incorporadas ao artigo.

Para os fins deste estudo foram definidos como produtos do agroextrativismo aos frutos nativos e seus produtos derivados de processos de beneficiamento - como óleos, cremes e farinhas. Mas foi necessário incorporar os produtos "aparentados": hortaliças e plantas alimentícias não convencionais, por exemplo, que são produtos às vezes espontâneos e às vezes cultivados, que ocupam na classificação dos produtores uma área difusa entre a agricultura e o extrativismo. Muitos produtos permaneciam nessa espécie de "zona cinzenta" entre produto agrícola e "produto do mato", como por exemplo araçá, jambo, jenipapo, cuja classificação êmica variava até entre vendedores de uma mesma feira, de modo que um feirante podia considerar aquela uma "fruta mansa" e outro considera-la "fruta brava do mato". Para resolver esse dilema adotou-se como critério assumir como originários do agroextrativismo todos os produtos que pelo menos uma vez fossem citados como tais, porque embora a literatura se esmere para definir a atividade, nem sempre as categorias usadas pelos agricultores se comportam de acordo com os preceitos da literatura.

\section{Agroextrativismo}

A intimidade dos agricultores familiares com a natureza permite que identifiquem e classifiquem espécies vegetais. Assim, desenvolvem culturas alimentares específicas, territorializadas e, às vezes, sustentáveis, que reúnem alimentação com produção e cultura, de modo a combinar também sustento alimentar e geração de renda. Isso acontece com o beneficiamento de produtos da agricultura transformados nas agroindústrias rurais, e ocorre no agroextrativismo (ANDRADE, 2016; BISPO, 2014). 
Carrara (2007) definiu agroextrativismo como o desenvolvimento histórico de ações interativas de populações locais com o ambiente, mesmo que esse ambiente tenha sido devastado por projetos de modernização agrícola. Segundo Bispo (2014) agroextrativismo é uma complementação produtiva praticada por agricultores familiares na unidade doméstica rural. A atividade é uma estratégia de sobrevivência e produção, pois o acréscimo na renda oriunda do extrativismo ocorre num período específico do ano agrícola, e de acordo com a espécie vegetal extraída da natureza poderá suprir consumo e/ou venda.

Conforme a legislação brasileira, o agroextrativismo é definido pela

“[...]combinação de atividades extrativas com técnicas de cultivo, criação e beneficiamento; é orientado para a diversificação, consórcio de espécies, imitação da estrutura e dos padrões do ambiente natural, e uso de técnicas geralmente desenvolvidas a partir dos saberes e práticas tradicionais, do conhecimento dos ecossistemas e das condições ecológicas regionais[...]" (BRASIL, 2009: 37).

Agroextrativismo pode contribuir para o desenvolvimento rural ao combinar atividades agrícolas e extração, gerar ocupação e renda por estimular relações densas da população com seu território, e por fortalecer a identidade cultural/alimentar e a soberania alimentar. A atividade é fundamentada, principalmente, nos conhecimentos e saberes tradicionais desenvolvidos num espaço específico. Agricultura, pecuária e extrativismo se complementam, podem se associar à sustentabilidade no uso do ambiente, no respeito às demandas sociais, culturais, políticas e aos princípios éticos comunitários. Desse modo, o agroextrativismo pode ter como marca a diversificação na produção dos alimentos e a geração de renda para agricultores proporcionada pelos recursos da natureza (MELO, 2013; BISPO, 2014; BISPO; DINIZ, 2014).

No Cerrado brasileiro há grande variedade de frutos nativos, saborosos e ricos em nutrientes. Esses frutos são característicos do bioma: têm gostos peculiares, às vezes considerados bastante exóticos, dependem de ciclos naturais de chuvas e estios, são adaptados ao meio, não precisam de manejo de solos e dependem de reduzido consumo de água - algo crucial no cenário crítico das mudanças climáticas. Populações tradicionais do cerrado desde sempre se alimentaram dos frutos nativos, dentre eles o pequi, gabiroba, jatobá, jacas ${ }^{1}$, araçá, mangaba, cagaita, bacuri, cajuzinho, buriti e murici. O pequi é, sem dúvida, um dos mais importantes (POZO, 1997; CARRARA, 2007; SILVA, 2009). 
A comercialização de produtos do agroextrativismo em feiras livres do Alto Jequitinhonha
Danilo Marinho Lamêgo Borges Vanessa Marzano Araújo

Eduardo Magalhães Ribeiro Maria Sirlene da Cruz Lucas Rocha Santos

E são agricultores familiares tradicionais que cumprem papel fundamental na conservação dessa organização agroecológica da produção. Pelos conhecimentos e práticas costumam ser denominados como "guardiões" dessa agrobiodiversidade, manejando um conhecimento agrícola que pode fundamentar produção diversificada, ética, orgânica, justa e ambientalmente sustentável; assim também podem inspirar e dar suporte a programas de desenvolvimento rural (DIABETÉ; QUARANTA, 2018; KIM, 2018; MALUF, 2018; MUSSOI \& ANJOS, 2018). Desse modo, territórios com forte presença de agricultores familiares e prática corrente do agroextrativismo podem transformar o potencial produtivo dos cerrados em ganhos efetivos para a população.

\section{O Alto Jequitinhonha}

O Alto Jequitinhonha foi ocupado por colonos que usavam de trabalho escravizado para buscar ouro e diamante no século XVIII. No século seguinte a mineração decaiu e perdeu importância; a agropecuária ganhou relevância, e décadas de partilhas sucessivas e mobilidade da população ocupando os espaços rurais conformaram uma agricultura de base familiar, assentada principalmente nas margens dos rios e córregos das "grotas", as partes baixas da paisagem, de vegetação arbórea e terras férteis. Grotas povoadas por "lavradores" - termo que os agricultores do lugar empregam para se definir - eram domínio de famílias extensas. Em cada grota, compartilhada pela grande descendência dos mesmos ancestrais, a família nuclear dispunha de área privativa para cultivo e criação e área de domínio comum, situada nas partes altas da paisagem, as "chapadas", planaltos de campos-cerrados, pouco férteis para a agricultura de coivara desses agricultores mas muito úteis para criação de gado "na larga", coleta de plantas de uso medicinal e "catação" de frutos nativos no tempo das chuvas (GRAZIANO \& GRAZIANO NETO, 1983; RIBEIRO, 2013).

A partir da década de 1960, com a "modernização agrícola" e o "milagre econômico", surgiram os programas para "integração econômica”, ou seja: iniciativas para identificar regiões de menor dinamismo para implantar políticas com propósito de incrementar a produção e a participação na economia. O Alto Jequitinhonha foi diagnosticado na época como um grande "vazio econômico" - economia concentrada no setor primário, com escassa diversificação de atividades e baixos níveis de renda per 
A comercialização de produtos do agroextrativismo em feiras livres do Alto Jequitinhonha
Danilo Marinho Lamêgo Borges Vanessa Marzano Araújo

Eduardo Magalhães Ribeiro Maria Sirlene da Cruz Lucas Rocha Santos

capita -, da mesma maneira que grande parte dos cerrados brasileiros. Essa concepção de desenvolvimento deu origem a projetos de grande escala com propósito de orientar investimentos para estimular a "integração" do Jequitinhonha; nos marcos da divisão regional de trabalho que vigorava então, deveria se tornar produtor de insumos: carvão vegetal para as siderúrgicas do centro de Minas Gerais. Assim foram criados programas de crédito para subsidiar empresas para plantar florestas homogêneas de eucaliptos. Entre 1975 e 1985 as "firmas" plantaram 500 mil hectares no Alto Jequitinhonha, o maior cultivo contínuo de eucaliptos do planeta (RIBEIRO, 2013).

A chegada das "firmas" de eucaliptos promoveu as tomadas de terras. As áreas comunitárias das chapadas foram griladas ou declaradas devolutas e arrendadas para empresas. Os agricultores das grotas perderam grande parte das terras de criação e coleta. Num quadro de elevada natalidade, característico de unidades familiares rurais, as condições de produção se tornaram muito difíceis: a mobilidade da roça de coivara foi seriamente limitada, a produtividade da terra declinou, as emigrações sazonais e definitivas se acentuaram. Desde então, receberam dos formuladores de políticas públicas a classificação de "população pobre", e daí surgiu o estigma do "Vale da Pobreza", que desde os anos 1980 inspirou dois tipos de programas estatais: programas compensatórios, com propósito de promover pequenas melhorias em itens básicos como produção e processamento agrícola; programas de grande escala focados em recursos naturais, com objetivo de explorar intensivamente terras, águas e minerais. Os efeitos desses programas no Território foram diversos. Programas compensatórios se esgotaram com seus próprios orçamentos. Programas de grande escala, exportando matéria prima - como madeira, minério e energia - para gerar valor em outras regiões, deixaram no Alto Jequitinhonha as mesmas lacunas da antiga mineração colonial (RIBEIRO, 2013).

A unidade familiar de produção pouco integrada aos mercados predomina no meio rural do Alto Jequitinhonha no século XXI, apesar da presença da extensa monocultura de eucaliptos nas chapadas, da mineração e das grandes barragens. Nas grotas se encontram famílias de agricultores "com suas casas de barrados coloridos, suas lavouras de mantimentos, as histórias das migrações, os costumes e as artes que o Brasil inteiro aprendeu a identificar como o vale do Jequitinhonha" (RIBEIRO \& GALIZONI, 2013, p. 30). Agricultores necessitam de "terras para lavouras, área pequenas para horta, 
canavial, mandiocal, pomar e mangueiro para o pasto dos animais de serviço”, e locais para "coletar frutos nativos, madeiras, lenha, plantas medicinais, embiras, ornamentos e argila" (RIBEIRO \& GALIZONI, 2013, p. 38).

As tomadas de terras pelas "firmas" de eucaliptos, a ocupação de margens de rios pelas barragens e o secamento das águas em decorrência da mineração provocaram sérias consequências negativas sobre o agroextrativismo. Agricultores familiares ficaram restritos praticamente às áreas das grotas e às fraldas das chapadas, os "campos" como denominam às terras pedregosas e pouco férteis na transição entre chapadas e grotas. Desse modo, a condição de coletar frutos nas chapadas ficou reduzida às poucas terras comuns que restaram. Mesmo essas, ficaram prejudicadas com a pressão do aumento do pastoreio e da coleta de lenha e madeira (RIBEIRO, 2013).

O Território do Alto Jequitinhonha é marcado pela concentração de chuvas no período de outubro a março, que divide claramente as estações entre chuvosa ("tempo das águas") e a seca ("tempo da seca"). Durante o período de chuvas de novembro e dezembro frequentemente as médias mensais de precipitação ficam em torno de 200 milímetros. O Território apresenta altitudes elevadas, parte da Serra do Espinhaço, o que resulta em incidência de chuvas orográficas. A temperatura média anual varia pouco, estando entre $21^{\circ} \mathrm{C}$ a $24^{\circ} \mathrm{C}(\mathrm{FJP}, 2017)$.

Por apresentar faixas de contato e transição entre biomas (Cerrado, Mata Atlântica e Caatinga), o Território do Alto Jequitinhonha tem variação no regime pluviométrico, diversidade de solos e um patrimônio muito relevante em biodiversidade. Isso é marcante em alguns municípios situados bem na faixa de transição, como Minas Novas, que no sentido leste-oeste vai dos campos da Serra do Espinhaço às cabeceiras do rio Mucuri na Mata Atlântica, e Itamarandiba, que no mesmo sentido vai das chapadas planas às matas do Alto rio Suaçuí-Grande, bacia do rio Doce. Nos dois municípios a extraordinária diversidade de vegetação característica de encontro de biomas se reflete nas feiras livres, que reúnem a produção característica da "mata" e do "campo", como definem os agricultores. Mas esse patrimônio natural é constantemente ameaçado pela "expansão do agronegócio, as pastagens plantadas, a produção de carvão vegetal, a mineração e as crescentes monoculturas de eucalipto e pinus", que tem promovido "desmatamentos, contaminação e assoreamento de nascentes, córregos e rios” (FJP, 2017, p. 32). Isso não 
inibe, entretanto, o vigor produtivo da agricultura familiar, que se manifesta publicamente na pujança das feiras livres.

Os municípios analisados neste artigo contavam em 2010 com população total de 101.762 habitantes, conforme o Censo do Instituto Brasileiro de Geografia e Estatística (IBGE). São municípios pouco populosos, todos com menos de 50 mil habitantes, com forte presença de população rural, bastante superior à média observada em Minas Gerais (Tabela 1). Dentre os municípios, Chapada do Norte e Minas Novas contavam com maior percentual da população residente no meio rural; mas Itamarandiba, Turmalina e Veredinha, mesmo tendo maior parcela da população no meio urbano, quando relacionadas a Minas Gerais, apresentavam percentual de população rural mais elevado que o dobro da média do estado. Todos os municípios em estudo fazem parte da Região Geográfica Imediata - RGI de Capelinha, que em percentual da população rural apresentava aproximadamente o triplo do percentual observado no estado de Minas Gerais.

Tabela 1 - Dimensão territorial, população total e percentuais de população urbana e rural em Minas Gerais e nos municípios estudados, 2010

\begin{tabular}{ccccc}
\hline Unidade & $\begin{array}{c}\text { Dimensão territorial } \\
\left(\mathbf{k m}^{\mathbf{2}}\right)\end{array}$ & $\begin{array}{c}\text { População } \\
\text { total }\end{array}$ & $\begin{array}{c}\text { População urbana } \\
\mathbf{( \% )}\end{array}$ & $\begin{array}{c}\text { População rural } \\
(\mathbf{\%})\end{array}$ \\
\hline Minas Gerais & $586.520,4$ & 19.597 .330 & 85,29 & 14,71 \\
RGI Capelinha & $10.158,0$ & 169.337 & 56,83 & 43,17 \\
Chapada do Norte & 831,0 & 15.189 & 37,49 & 62,51 \\
Itamarandiba & $2.735,6$ & 32.175 & 68,34 & 31,66 \\
Minas Novas & $1.812,4$ & 30.794 & 40,87 & 59,13 \\
Turmalina & $1.153,1$ & 18.055 & 71,59 & 28,41 \\
Veredinha & 631,7 & 5.549 & 67,92 & 32,08 \\
\hline
\end{tabular}

Fonte: Censo Demográfico 2010 (IBGE, 2010). Organizada pelos autores, 2020.

É importante destacar, ainda, que esses municípios não contam apenas com grande população rural: trata-se de uma população rural constituída em sua maior parte por agricultores familiares. Na região de Capelinha eucaliptais ocupam $24 \%$ da área rural e $4 \%$ da força de trabalho; embora explore apenas $32 \%$ da área total das terras, a agricultura familiar ocupa $87 \%$ da força de trabalho rural (RIBEIRO, 2013). Esses agricultores usam técnicas de baixo consumo de insumos, usam de fertilidade natural, sementes de variedades adaptadas (“de paiol”) e trabalho familiar. A produção agrícola é trocada na comunidade, vendida nas vizinhanças e na sede do município. Neste, o principal canal de escoamento da produção é a feira livre semanal (GALIZONI et al., 2019b). 


\section{Feiras livres}

Mercados e feiras livres, ao longo da história, foram pilares para expansão do comércio e para abastecimento das cidades (SERVILHA, 2008; CRUZ et al., 2019). ${ }^{2}$ No Brasil a existência de feiras remete ao período colonial. Esses espaços são apropriados para transações econômicas e trocas mercantis de alimentos, apresentando também grande importância para sedimentar relações sociais e manifestações culturais. O vai e vem cotidiano das pessoas nos mercados revela a fluidez e da intensidade das relações sociais dentro da comunidade (SERVILHA, 2008; ARAÚJO \& RIBEIRO, 2018).

Segundo Ribeiro (2007, p.84) “a feira livre é uma das instituições mais sólidas de Minas Gerais, principalmente no Norte, Nordeste e Noroeste do estado". Feiras apresentam a diversidade da produção do lugar, exibem as singularidades regionais e têm grande efeito sobre a economia dos municípios; resultam em renda para feirantes na comercialização de produtos, geram renda para comerciantes urbanos, abastecem consumidores, além de aproximar produtores, vendedores e consumidores (RIBEIRO, 2007; SERVILHA, 2008; ARAÚJO \& RIBEIRO, 2018).

A feira livre ultrapassa o plano das transações econômicas: é uma mostra das características específicas de uma população. A atividade começa nas unidades domésticas rurais, com a produção, passa pela escolha dos produtos que devem ser destinados para a comercialização, em seguida entra o transporte dos produtos e a organização do espaço ou da banca nas primeiras horas do dia, antes da chegada da clientela (SERVILHA, 2008). Conforme Ribeiro (2007) a oferta varia no decorrer do ano conforme as estações, períodos da seca e das águas. No Alto Jequitinhonha, feiras vendem hortaliças, frutas da estação, legumes, animais vivos, farinhas de mandioca e de milho, "gomas" ou polvilhos, biscoitos e pães caseiros, doces, rapaduras, plantas alimentícias não convencionais e de uso medicinal. Desse modo, são importantes para populações urbanas porque oferecem oportunidade de escolher o que consumir, permitem conservar hábitos alimentares localizados, baseados em alimentos próprios do território, que apresentem qualidade reconhecida, e muitas vezes são produzidos com métodos orgânicos. Representam, por fim, modalidade de canal de comercialização que escoa a produção por meio de circuitos curtos (RIBEIRO, 2007; SERVILHA, 2008; CRUZ, 2019; CRUZ et al., 2019). 
A comercialização de produtos do agroextrativismo em feiras livres do Alto Jequitinhonha
Danilo Marinho Lamêgo Borges Vanessa Marzano Araújo

Eduardo Magalhães Ribeiro Maria Sirlene da Cruz Lucas Rocha Santos

A onda conservacionista que emergiu depois da revolução verde faz com que consumidores procurem controlar a qualidade dos alimentos para garantir sua própria saúde. Isso tem sido feito reunindo informações sobre produtor, processos de produção e origem dos produtos. Assim, passaram a valorizar canais de comercialização que favorecem o contato entre consumidores e produtores, e daí vem a importância dos denominados "circuitos curtos" de comercialização.

Esses circuitos foram analisados por vários autores. Darolt, Lamine e Brandemburg (2013) os definiram como uma "nova mentalidade", que sedimenta relações de trocas próximas entre produtores e consumidores e se contrapõe ao modelo convencional de negócios com alimentos. As relações espaciais e territoriais de proximidade dos circuitos curtos estimulam a diversificação da produção e as trocas justas e solidárias, que, ao mesmo tempo, podem estimular o desenvolvimento rural e a territorialização da alimentação, ao reforçar a autonomia alimentar dos territórios e ampliar o protagonismo dos agentes que respondem pela produção e pelo consumo dos alimentos. A comercialização por meio dos circuitos curtos acontece, fundamentalmente, pela venda direta, situação na qual o produtor entrega a mercadoria para o consumidor; em seguida pela venda indireta, nas situações em que existe apenas um intermediário (DAROLT \& LAMINE; BRANDEMBURG, 2013).

No circuito curto de comercialização da feira livre observa-se que, entre os participantes, existem trocas materiais e simbólicas que vão além da troca monetária produto-dinheiro: há trocas de palavras, histórias, notícias, amizade e bens. Na condição de ponto de contato entre pessoas a feira contribui para sedimentar uma cultura alimentar no território graças aos encontros que promove entre produtor e consumidor e pela oferta de produtos que expressam a preferência e o costume alimentar das localidades; assim se tornam canais de oferta do alimento relacionado ao costume, à história e à preferência, ou seja: alimentos associados à soberania alimentar (SERVILHA, 2008).

$\mathrm{O}$ ato de alimentar tem um forte componente cultural, que se relaciona com a diversidade de ingredientes e o modo de preparo dos alimentos. Alimento se associa ao modo de convivência das populações com o território, e é aí que interfere a soberania alimentar: o direito de se alimentar em acordo com sua cultura. $\mathrm{O}$ termo segurança alimentar teve origem nos embates com as políticas econômicas neoliberais e as grandes 
empresas agroalimentares; no Brasil os conceitos de soberania e segurança alimentar foram disseminados ao mesmo tempo e relacionados ao direito humano à alimentação (MALUF, 2018).

Segurança alimentar diz respeito à garantia da produção e oferta de alimentos para as populações. Com o aumento da população mundial, cresce a demanda por alimentos, o que resulta em aumento na pressão da produção agrícola sobre o meio ambiente. Segundo estimativa da FAO (2014), no planeta existem 805 milhões de pessoas que passam fome; nesse cenário, o debate sobre o direito humano à alimentação tem ganhado forças e o fortalecimento da agricultura familiar é uma possibilidade de melhorar a oferta de alimentos de qualidade, pautada pela sustentabilidade econômica, social e ambiental (BRASIL, 2014).

Assim, valorizar alimentação de qualidade significa conservar a saúde da população, mas implica também em valorizar a cultura local, o sentimento de identidade e pertencimento, proporcionar justiça social, mercados justos para consumidores e produtores. Reunidas, soberania e segurança alimentar valorizam aquilo que a literatura vem denominando como "comida de verdade": o alimento posto numa perspectiva crítica à comida industrializada ou ao "fordismo alimentar", que tenha por base a produção agrícola territorializada, diversificada, fundamentada em produtos de grande valor genético, e produtores que assumem responsabilidades com o ambiente, os recursos naturais e os cidadãos. Comida de verdade, nesse sentido, é o alimento de origem natural com mínimo processamento, que tenha qualidade nutricional e biológica, e valor agregado pela conservação da biodiversidade (MARTINEZ, 2013; BARRERA, 2011; MALUF, 2018; DIAS et al., 2018).

É dentro desse cenário que o agroextrativismo deve ser compreendido. A população do Cerrado interage com o ambiente para coletar os frutos nativos característicos do bioma. Na agricultura familiar, a atividade é um meio de valorizar costumes e cultura, abrindo também oportunidades de renda e ocupação. Nas feiras livres, agroextrativismo sedimenta a interação entre vendedores e compradores, aproxima as pessoas pela frequência das trocas, territorializa a dieta, valoriza programas concebidos na escala do município e do território. 


\section{Agroextrativismo no rural}

O agroextrativismo faz parte dos costumes da população do Alto Jequitinhonha. No século XIX, Saint-Hilaire (1975) já registrava as muitas plantas usadas como alimento e remédio produzidas nas chapadas de Itamarandiba a Minas Novas, que então era sede do termo. Décadas depois, Graziano \& Graziano Neto (1983) apontavam a grande importância dos frutos, ervas e raízes coletados nas chapadas para o sustento e a saúde da população. No começo do século XXI, Calixto (2002) registrou a diversidade de plantas e frutas das chapadas que recebiam usos medicinais, confortavam os moradores das áreas rurais e eram objeto de conhecimento judicioso de raizeiros. Segundo a autora, cada comunidade - ou seja: cada agrupamento de família extensa - dispunha de pelo menos um especialista na arte de coletar, preparar e ministrar saúde usando recursos da natureza.

Esses costumes são persistentes: num estudo de 2019 em seis comunidades rurais do rio Fanado, entre os municípios de Minas Novas e Turmalina, Galizoni et al. (2019b) apontaram que todas as famílias tinham o costume de coletar produtos da natureza: frutas nativas, mas também madeira, lenha, argila e plantas de uso medicinal. Coletavam frutas em grande quantidade e diversidade; "catavam" pequi, mangaba, jatobá, gravatá, gabiroba, murici, cagaita, jaca-panã, jerivá, coquinho-do-mato, cajuzinho, maracujá-domato e sapotá. Como há margem para dúvidas na definição de fruto nativo, pois assim se pode entender tanto "fruto do mato" quanto "fruto não cultivado", na relação de frutos nativos aparecia também jabuticaba

Mas algumas das frutas nativas coletadas eram preferidas às outras, por ter uso mais frequente, ocupar lugar destacado nas refeições principais ou, mesmo, pela disseminação e frequência da árvore no cerrado. Então, pesa o fato que, legalmente, desde os anos 2000 é vedado o corte do pequizeiro e liberada a coleta do fruto; de modo que o pequizeiro não apenas produz um fruto apreciado, mas também tende a ser árvore disseminada e protegida. Assim, Galizoni et al. (2019b) indicaram que variava o percentual de famílias que consumiam frutos nativos: pequi $(87,72 \%)$, mangaba $(56,14 \%)$, panã $(45,61 \%)$, gabiroba $(24,56 \%)$ e jatobá $(21,05 \%)$. E havia também as plantas de uso medicinal; os autores computaram que 40,35\% das famílias rurais tinham o costume de coletar e consumir essas plantas. A coleta de frutas nativas e ervas 
medicinais ocorria menos em chapadas $(54,39 \%)$ que em grotas $(73,68 \%)$, mesmo que as chapadas sejam naturalmente mais produtivas em frutos.

A tomada de terras pelas "firmas" nos anos 1970 reduziu as áreas de chapadas que permaneceram sob controle de comunidades rurais, e as chapadas privatizadas foram desmatadas e convertidas em plantio homogêneo de eucalipto. Nas franjas das chapadas restaram trechos de "campos" na descida para as grotas, áreas que conservaram vegetação nativa e abrigam a maior parte das fruteiras nativas, de modo que a escassez provocada pela tomada de terras é muito sentida pela população. Num depoimento publicado em 2019, Faustina Lopes da Silva, especialista tradicional em preparo de alimentos, descreveu a dificuldade para conseguir frutos nativos:

\footnotetext{
"Tem alguns alimentos que usa de pegar na natureza. Tem o pequi, a jaca. A gente não tem mais lugar de buscar porque tinha na chapada, e agora na chapada só tem eucalipto. Mas ainda tem algum pedacinho de chapada que tem uns pés de jaca. Então a gente está plantando, ou buscando onde tem. Mas está difícil, ficou difícil depois do eucalipto, e uns pés de pequi ficaram no povoado - cada um que tem seu lote e tem um pé de pequi, zela. Mas fora, fica difícil. No campo, tem sapotá, o bacupari - uma fruta muito saudável. (SILVA, 2019: 72).
}

O fruto se tornou escasso, mas sua busca era persistente. Galizoni et al. (2019a) observaram que $84,21 \%$ das famílias destinavam os frutos de coleta para consumo próprio, apenas parte reduzida era destinado à comercialização. Assim, nas feiras livres apareceria apenas fração do total do produto coletado, mas havia correspondência em termos de preferência, pois se o pequi era a fruta nativa mais coletada e consumida nas comunidades rurais, também será o fruto nativo com maior presença nas feiras livres, conforme se lerá adiante. E, dentre as demais frutas nativas, algumas vão aparecer com relativa frequência nos pontos de vendas das feiras: mangaba, panã, jatobá, murici, gravatá ou palmito, e maracujá-do-mato. No rural, como indicou o mesmo estudo, a totalidade das plantas de uso medicinal era destinada ao consumo da própria família, destacando que esses autores perceberam, do mesmo modo que Calixto (2002), que a diversidade de ervas e raízes coletada para o próprio consumo era muito maior que aquela encontrada nas feiras.

Desse modo, é possível afirmar que o consumo urbano de frutos e plantas medicinais, e enfim de produtos da natureza, reflete o perfil do consumo rural indicado pela literatura. É, porém, uma cópia muito específica, em menor escala, e mediada pelas trocas, pelas distâncias e pela sazonalidade. 


\section{Agroextrativismo nas feiras livres}

As feiras costumam ter o tamanho das cidades que as desenvolvem. Cruz et al. (2019) dimensionaram as feiras do Jequitinhonha computando o número de feirantes. A maior das feiras em Itamarandiba, a maior das cidades pesquisadas, contava com média de 302 feirantes; as duas áreas urbanas de dimensão menor, em seguida, Turmalina e Minas Novas, contavam com 178 e 160 feirantes, respectivamente. Por fim, Chapada do Norte e Veredinha apresentavam menor número de feirantes, com 45 e 51 respectivamente. Relacionando número de feirante com o total de agricultores familiares computados pelo Censo Agropecuário nos municípios em 2006 (Tabela 2), é possível perceber que não há relação direta entre os dois valores. Isso é devido às dimensões do consumo alimentar na sede municipal, aos programas locais de estímulo às feiras, às distâncias e condições de transporte. Itamarandiba e Turmalina apresentaram maior participação percentual de agricultores familiares nas feiras livres: $17,19 \%$ e 19,28\% respectivamente.

Tabela 2 - Número de famílias feirantes e de agricultores familiares nos municípios pesquisados.

\begin{tabular}{cccc}
\hline Município & Número de feirantes & $\begin{array}{c}\text { Número de agricultores } \\
\text { familiares }\end{array}$ & $\begin{array}{c}\text { Percentual de } \\
\text { agricultores feirantes }\end{array}$ \\
\hline Chapada do Norte & 45 & 1.879 & $2,39 \%$ \\
Itamarandiba & 302 & 1.757 & $17,19 \%$ \\
Minas Novas & 160 & 2.772 & $5,77 \%$ \\
Turmalina & 178 & 923 & $19,28 \%$ \\
Veredinha & 51 & 597 & $8,54 \%$ \\
\hline Total & 736 & 7.928 & $9,28 \%$ \\
\hline
\end{tabular}

Fonte: Cruz et al.(2019).

Dispondo de informação sobre o total de pontos de vendas, é possível agora dimensionar a participação dos produtos do agroextrativismo nas feiras livres. $\mathrm{O}$ percentual de pontos de vendas desses produtos em relação ao total dos pontos de vendas nos cinco municípios está exposto no Gráfico 1 . Grandes variações ocorrem ao longo do ano. Há uma arrancada na oferta dos produtos nativos a partir de dezembro de 2018 que encontra seu pico em janeiro de 2019 quando alcança perto de $9 \%$ do total de pontos de vendas; partindo desse pico, a oferta encontra o menor percentual da série em junho de 2019, quando alcança menos de $2 \%$ dos pontos de vendas.

Observa-se que o pico da oferta de produtos nativos acontece no auge do verão e da estação das chuvas: dezembro, janeiro, fevereiro; o ponto mais baixo da oferta 
A comercialização de produtos do agroextrativismo em feiras livres do Alto Jequitinhonha
Danilo Marinho Lamêgo Borges Vanessa Marzano Araújo

Eduardo Magalhães Ribeiro Maria Sirlene da Cruz Lucas Rocha Santos

corresponde aos meses mais frios, à "boca da seca" como dizem os agricultores, que, embora chova pouco ou nada nesses municípios, ainda não serão os meses mais secos. A "quadra" pior de seca vem nos meses de setembro, outubro e novembro, quando os reservatórios de água minguam e as forragens estão secas. Há, portanto, relação inversa entre a safra agrícola e a safra do agroextrativismo. Nesses municípios a safra agrícola acontece a partir de março e se estende até junho, quando começa a produção das hortas e da indústria doméstica rural que irá até novembro com "fábrica" ativa de rapadura, açúcar-mascavo e cachaça nos engenhos de cana-de-açúcar e "tendas" produzindo farinha de mandioca, "goma" ou polvilho e farinha de milho.

Gráfico 1 - Pontos de vendas de produtos do agroextrativismo como percentual do total de pontos de vendas das feiras livres dos 5 municípios, 2018/2019.

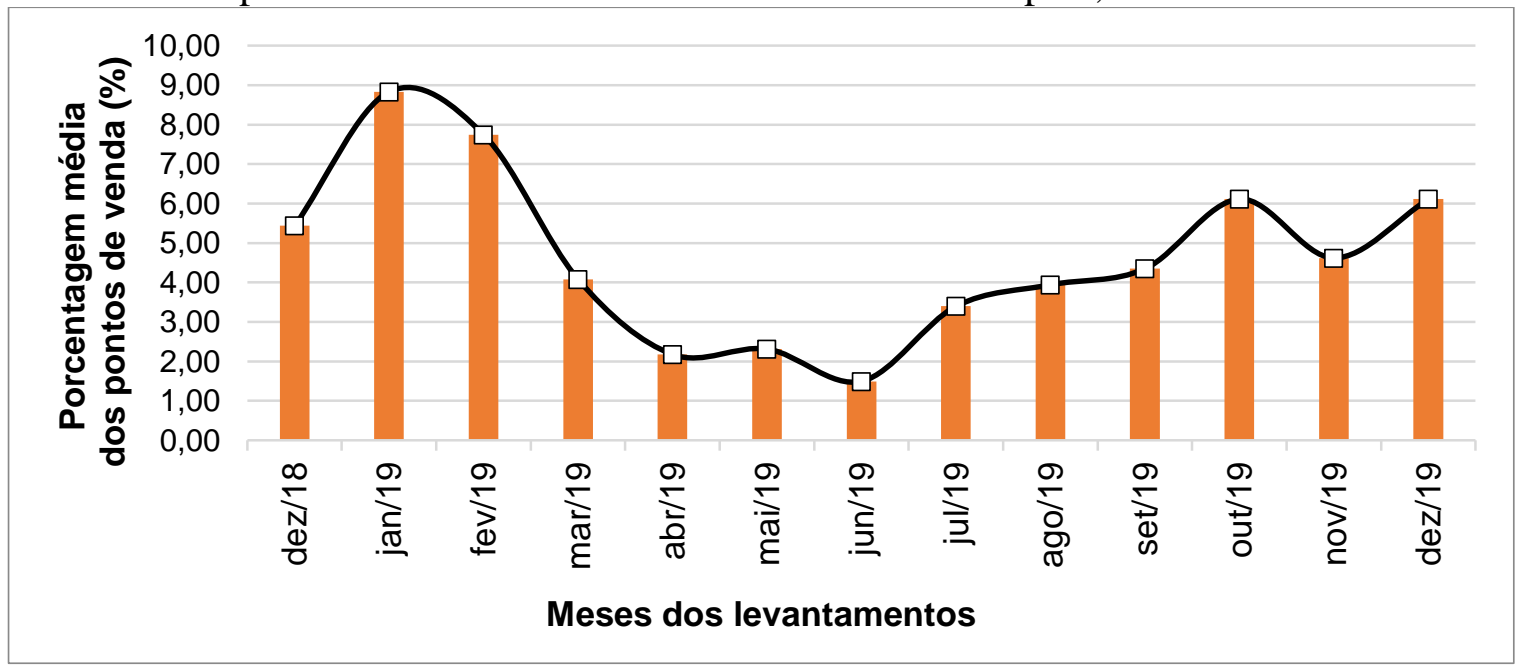

Fonte: dados da pesquisa de campo 2018/19. Organizada pelos autores, 2020.

O pico observado em dezembro/fevereiro se deve à comercialização do principal produto nativo, o pequi, nas cinco feiras. Nos meses de janeiro a junho observa-se a queda na participação percentual do agroextrativismo em pontos de vendas, que vai de 8,83 a $1,49 \%$ do total. No período da seca, de junho a novembro há um lento crescimento de oferta, que já se associa à comercialização dos produtos processados da madeira, plantas alimentícias não convencionais e plantas medicinais.

A curva de oferta dos frutos e ervas nativos traduz os ciclos da pauta alimentar rural do Território: de dezembro a março há ênfase no agroextrativismo, que se reduz no correr do ano, quando ganha projeção a alimentação vinda da lavoura, da horta e dos 
engenhos. Esse ciclo foi registrado por dois especialistas em tradição alimentar do Alto Jequitinhonha, João Antônio Gonçalves de Souza e Etelvino Alves de Azevedo: indicaram que a lavoura não provê os mantimentos durante todo o ano. O esgotamento dos estoques dos paióis e tulhas por volta de novembro, à espera da maturação da lavoura plantada em outubro/novembro, e a oportunidade da safra de produtos nativos, induzia ao aproveitamento da safra dos frutos das chapadas, que se tornava excelente complemento para o sustento das famílias rurais (SOUZA, 2019; AZEVEDO, 2019).

Por isso, refletindo os costumes da alimentação no mundo rural em todos os municípios há forte presença de produtos "do mato" nos pontos de vendas durante o auge do verão. E uma similaridade ainda maior foi observada na feira livre de Turmalina, que apresentou dois momentos de pico da oferta dos produtos do agroextrativismo: o primeiro em dezembro na comercialização do pequi e o segundo com produtos nativos processados, plantas alimentícias não convencionais e plantas de uso medicinal, no meio do ano. Esses produtos são, efetivamente, importantes, e respondem pelo crescimento de oferta a partir de junho, até a chegada da safra de pequi. Mas as discrepâncias no comportamento da oferta desses produtos entre os municípios se devem, principalmente, às condições do clima. No verão, em alguns dos municípios, a chuva afeta drasticamente o transporte para a feira livre e influi no número de pontos de vendas. Chuva afeta também o trabalho de coletar e organizar a produção no dia anterior à feira, afetando assim o escoamento da produção das unidades domésticas rurais até as feiras.

\section{Diversidade}

Além de participação relevante em termos de pontos de vendas, produtos do agroextrativismo se destacam nessas feiras pela diversidade. Entre dezembro de 2018 e dezembro de 2019 foram identificados 51 desses produtos nas feiras livres, que ficam marcadas com suas cores, aromas e sabores. Nas feiras aparecem os frutos nativos de cerrado, panã ou cabeça de nego, mangaba e maracujá do mato, mas não faltam óleos e bebidas, como o vinho de jurubeba de reputado poder curativo para males do estômago, ou alimentos: broto de samambaia, frequente em Itamarandiba; palmito nativo em Itamarandiba e Veredinha; cuia e coco jerivá em Chapada do Norte, conforme o Quadro 1. É preciso novamente ressalvar que vários produtos foram identificados pelos feirantes 
como nativos por serem espontâneos, caso das plantas alimentícias não convencionais como serralha, ora-pro-nobis e gondó, considerados nativos por não serem cultivados. $\mathrm{O}$ conjunto dos produtos têm usos na alimentação, mas também são medicinais, ornamentais e, até, instrumentos de trabalho - como os cabos de enxada de madeira nativa, que são amplamente preferidos porque não esquentam na fricção do serviço braçal e deixam as mãos sem calos.

Quadro 1 - Diversidade e número de produtos do agroextrativismo nas feiras livres de Chapada do Norte, Itamarandiba, Minas Novas, Turmalina e Veredinha, 2018/2019

\begin{tabular}{|c|c|c|}
\hline Localidade & $\begin{array}{c}\text { Número de } \\
\text { produtos }\end{array}$ & Produtos \\
\hline Chapada do Norte & 12 & $\begin{array}{l}\text { Coco jerivá, coquinho do mato, cuia, mangaba, maxixe liso, maxixe } \\
\text { fofo, óleo de pequi, panã, pequi caroço, pequi fruto, serralha e umbu. }\end{array}$ \\
\hline Itamarandiba & 27 & $\begin{array}{l}\text { Balaio de bambu, broto de samambaia, bucha vegetal, cabo de } \\
\text { enxada de madeira nativa, cagaita, conserva de pequi, gondó, jambo, } \\
\text { jatobá, mangaba, maxixe liso, mel silvestre, óleo de coco indaiá, } \\
\text { óleo de mamona, óleo de pequi, ora-pro-nóbis, palmito, panã, pequi } \\
\text { caroço, pequi fruto congelado, pequi fruto, pilão de madeira, plantas } \\
\text { medicinais, serralha, taquara e vassoura de coqueiro. }\end{array}$ \\
\hline Minas Novas & 33 & $\begin{array}{l}\text { Araçá, balaio de bambu, broto de samambaia, bucha vegetal, cabo } \\
\text { de enxada de madeira nativa, cagaita, coité, colher de pau, gondó, } \\
\text { jaca do mato, jambo, jatobá, jenipapo, jurubeba, mangaba, maxixe } \\
\text { fofo, mel silvestre, murici, óleo de coco macaúba, óleo de mamona, } \\
\text { óleo de pequi, ora-pro-nóbis, palmito, panã, pequi caroço congelado, } \\
\text { pequi caroço, pequi fruto, pilão de madeira, plantas medicinais, } \\
\text { serralha, taquara, vassoura de coqueiro e vinho de jurubeba. }\end{array}$ \\
\hline Turmalina & 26 & $\begin{array}{l}\text { Agriãozinho, balaio de bambu, canela de velho, dente de leão, } \\
\text { farinha de jatobá, gondó, jambo, mangaba, maracujá do mato, } \\
\text { maxixe fofo, mel amargo, mel silvestre, óleo de coco macaúba, óleo } \\
\text { de mamona, óleo de pequi, ora-pro-nóbis, panã, pequi caroço } \\
\text { congelado, pequi caroço, pequi fruto, pinha, plantas medicinais, } \\
\text { serralha, umburana, utensílios de madeira e vinho de jurubeba. }\end{array}$ \\
\hline Veredinha & 17 & $\begin{array}{l}\text { Balaio de bambu, gondó, macaúba, mangaba, maracujá do mato, } \\
\text { maxixe fofo, mel silvestre, óleo de coco macaúba, óleo de mamona, } \\
\text { óleo de pequi, ora-pro-nóbis, palmito, panã, pequi caroço, pequi } \\
\text { fruto, serralha, vinho de jurubeba. }\end{array}$ \\
\hline
\end{tabular}

Fonte: Pesquisa de campo, 2018/2019. Organizada pelos autores, 2020.

É importante destacar que, dentre todos os 51 produtos, com maior ou menor frequência, 32 produtos se repetem. Entre estes, existem alguns com alta frequência de repetição: mangaba, maxixe fofo (ou "maxixe badaró", como se diz em Minas Novas), panã, pequi e serralha apareceram em todas as feiras; e balaios, gondó, óleo de mamona e ora-pro-nobis estiveram em quatro das feiras municipais no correr do ano. Mas, 19 deles 
A comercialização de produtos do agroextrativismo em feiras livres do Alto Jequitinhonha
Danilo Marinho Lamêgo Borges Vanessa Marzano Araújo

Eduardo Magalhães Ribeiro Maria Sirlene da Cruz Lucas Rocha Santos

não se repetiram, ou seja, quase $40 \%$ dos produtos apareceram exclusivamente na feira de um município, revelando as singularidades da biodiversidade, dos ambientes e a peculiaridade dos próprios costumes locais. Não é muito difícil relacionar a diversidade com as características dos diferentes municípios, e indicar que, nos municípios onde o leque de produtos ofertados é maior, também é maior a superfície e, principalmente, o compartilhamento e proximidade de áreas de Cerrado e Mata Atlântica, casos de Turmalina, Minas Novas e Itamarandiba. Não por acaso com menor oferta, Chapada do Norte fica na transição para Caatinga, já no Semiárido oficial, e enfrentava na época da pesquisa o sexto ano seguido de precipitações muito irregulares.

Outra abordagem possível para a diversidade dos produtos é a análise por categorias, apresentada na Tabela 3.

Tabela 3 - Categorias de produtos do agroextrativismo presentes nas feiras livres dos municípios, discriminados por quantidade total de pontos de vendas de dezembro de 2018 a dezembro 2019.

\begin{tabular}{lcc}
\hline Categoria & $\begin{array}{c}\text { Quantidade de } \\
\text { pontos de vendas }\end{array}$ & $\%$ \\
\hline Pequi e derivados & 528 & 64,16 \\
Frutas nativas & 54 & 6,56 \\
Produtos beneficiados & 100 & 12,15 \\
Plantas alimentícias não convencionais (PANCs) & 83 & 10,09 \\
Medicinais & 27 & 3,28 \\
Diversos & 31 & 3,77 \\
\hline TOTAL $\quad$ Fonte: pesquisa em campo, 2018/19. Organizada pelos autores, 2020.
\end{tabular}

Nesta foram categorizados em pequi e derivados, que contempla os produtos oriundos do pequi; frutas nativas, como cagaita, coquinho do mato, panã, mangaba, jambo, maracujá do mato, murici, araçá, coco jerivá, jaca do mato, jatobá, jenipapo, pinha, umbu; produtos beneficiados, categoria relacionada aos produtos processados como vinho de jurubeba, farinha de jatobá, derivados de madeira e taquara, óleo de mamona, óleo de cocos, balaio de bambu, colher de pau, cuia e vassoura de coqueiro; plantas alimentícias não convencionais (PANCs), categoria relacionada as hortaliças nativas como maxixe fofo, serralha, gondó, broto de samambaia e ora-pro-nóbis; medicinais, categoria relacionada com os conhecimentos territoriais de saúde, como canela de velho, dente de leão, espinheira santa, jalapinha, arnica, carqueja, maracujina, 
monjola, quitoco, dentre outras; e diversos, categoria que contempla os produtos de palmito, bucha e mel selvagem e amargo.

Dessas categorias supracitadas destacaram-se a do pequi e derivados, que corresponderam a $64,16 \%$ dos pontos de vendas quantificados nas feiras livres. Em seguida produtos beneficiados com $12,15 \%$, plantas alimentícias não convencionais com $10,09 \%$, frutas nativas com $6,56 \%$, diversos: $3,77 \%$ e plantas medicinais com $3,28 \%$ de representatividade entre os pontos de vendas. Desse modo, percebe-se que, embora existam muitas categorias de produtos representadas, algumas apresentam maior expressividade em pontos de vendas, e certamente maior importância econômica e cultural nas feiras.

É preciso lembrar, no entanto, que aqui se trata de produtos que apresentam forte variação sazonal e grande diversidade, e isso torna limitada a possibilidade de análise puramente quantitativa. Desse modo, produtos de menor frequência - como mangaba, por exemplo - não deixam de ser importantes nas vendas, na dieta e na cultura. A sazonalidade dos produtos é muito acentuada. Dentre esses, com ciclo muito próprio, de oferta bem demarcada no tempo e muito perecíveis, destacam-se panã, jambo e mangaba. E outros produtos, como os diversos óleos de cocos, aparecem nas feiras livres na estação seca, que coincide com a época que as famílias rurais se dedicam ao processamento dos produtos costumeiros como mandioca, milho e cana-de-açúcar, mas também parece ser a época de agregar valor aos frutos nativos para reduzir a perecibilidade e diversificar suas possibilidades de uso.

Um produto que aparece em período muito determinado nas feiras livres é a panã, fruta nativa que começa aparecer nos pontos de venda por volta dos meses de fevereiro e março, e tem freguesia cativa na sua temporada. A mangaba apareceu de forma muito rápida nos meses de dezembro e fevereiro. Nos municípios em estudo os feirantes relataram que entre o final de 2018 e início de 2019 foi bastante fraca a produção de frutos da mangaba. Fruta considerada nativa pelos agricultores e passageira nas feiras livres é o jambo, que aparece nos meses de dezembro, janeiro e fevereiro, períodos normalmente chuvosos, quando maturam os frutos nas margens dos córregos e rios da região.

Serralha, uma planta alimentícia não convencional, apareceu nas feiras nos meses de dezembro, abril, maio, julho, setembro, outubro e novembro; esta, por ser uma 
A comercialização de produtos do agroextrativismo em feiras livres do Alto Jequitinhonha
Danilo Marinho Lamêgo Borges Vanessa Marzano Araújo

Eduardo Magalhães Ribeiro Maria Sirlene da Cruz Lucas Rocha Santos

hortaliça nativa, desenvolve espontaneamente, potencializada pelo solo muito adubado de beiras de hortas e currais, com baixo consumo de água e energia, o que pode ser comprovado pelos diversos períodos em que aparece nos pontos de vendas. O palmito, também apresenta sazonalidade, aparecendo nas feiras nos meses de setembro, outubro, novembro, dezembro, janeiro e julho.

\section{Oferta e preço do pequi}

O pequi e seus derivados têm destaque em todas as feiras livres: é o principal produto comercial do agroextrativismo. $\mathrm{O}$ fruto ao natural está presente nas cincos feiras de dezembro a março, mas em alguns municípios a comercialização se estende até junho com oferta do fruto congelado, conforme observado em Minas Novas e Turmalina. Transformado em óleo, o pequi é ofertado durante o ano inteiro.

Pequi é o fruto do pequizeiro, espécie nativa do Cerrado, de médio porte, planta que se desenvolve em solos pobres em nutrientes minerais e com alto teor de alumínio. Árvore de Cerrado, suas caraterísticas morfológicas são adaptadas a esse bioma: tronco retorcido, folhas ásperas, casca espessa, ramos grossos e angulosos e raízes profundas (LOPES et al., 2006). Segundo Oliveira (2010, p. 17) "as folhas do pequizeiro são fáceis de reconhecer, com três 'dedos' no final do ramo, são grandes e com pequenos pelos nos dois lados da folha, e possuem as bordas recortadas." As folhas caem no início da estação seca, por volta de junho ou julho; a floração vai acontecer junto com o desenvolvimento de novas folhas, já na metade da estação seca, e o término da floração ocorre com as primeiras chuvas. Há certa variação na maturação, que acontece no sentido norte/sul; no Norte de Minas Gerais e Alto Jequitinhonha os frutos começam amadurecer em meados de novembro, a produção se estende até fevereiro, antes do término da estação chuvosa, mas o pico da safra acontece entre dezembro e janeiro (LOPES et al., 2006).

O sabor do fruto do pequi é único e exótico. Isso dá margem a divergências nas avaliações de gosto. No entanto, é um produto consagrado na culinária, dando origem a uma quantidade de produtos que vão do caroço assado do fruto até a polpa em conserva, do óleo ao licor, até a paçoca da amêndoa (AVIDOS \& FERREIRA, 2000; CANÊDO, 2014; OLIVEIRA, 2010). Embora sejam muitos os usos possíveis, os consumidores compram pequi na feira é mesmo para "roer" o caroço: cozinhar o fruto de polpa grossa (a "carne do 
A comercialização de produtos do agroextrativismo em feiras livres do Alto Jequitinhonha
Danilo Marinho Lamêgo Borges Vanessa Marzano Araújo

Eduardo Magalhães Ribeiro Maria Sirlene da Cruz Lucas Rocha Santos

pequi”, como se diz) na água, no arroz ou no arroz com frango, temperar e comer, tomando cuidado para não quebrar a casca, porque dentro do caroço tem espinhos: é por isso que o fruto cozido é roído com cuidado, evitando quebrar a casca e encher a boca de espinhos. Mas caroços e polpa podem também passar por mínimo de processamento para ser armazenado; congelado ou em conserva o produto ganha durabilidade (POZO, 1997). Tendo muitos usos, o pequi aparece nas feiras sob várias formas.

A dinâmica de oferta e preço pode ser percebida no Gráfico 2, que mostra a relação entre o número de pontos de venda e o preço da dúzia do pequi. A safra do pequi, em quase todos os municípios estudados, começa em dezembro e vai até março; em Itamarandiba, mais ao sul, há um pequeno atraso, e a safra local começa a partir de janeiro. A tendência de preços da dúzia do pequi no decorrer da safra tem relação inversa com a oferta do produto, dimensionada em termos de número de pontos de vendas.

Gráfico 2 - Pontos de vendas e preços da dúzia de pequi durante a safra nas feiras livres de Chapada do Norte, Itamarandiba, Minas Novas, Turmalina e Veredinha, 2018/2019.

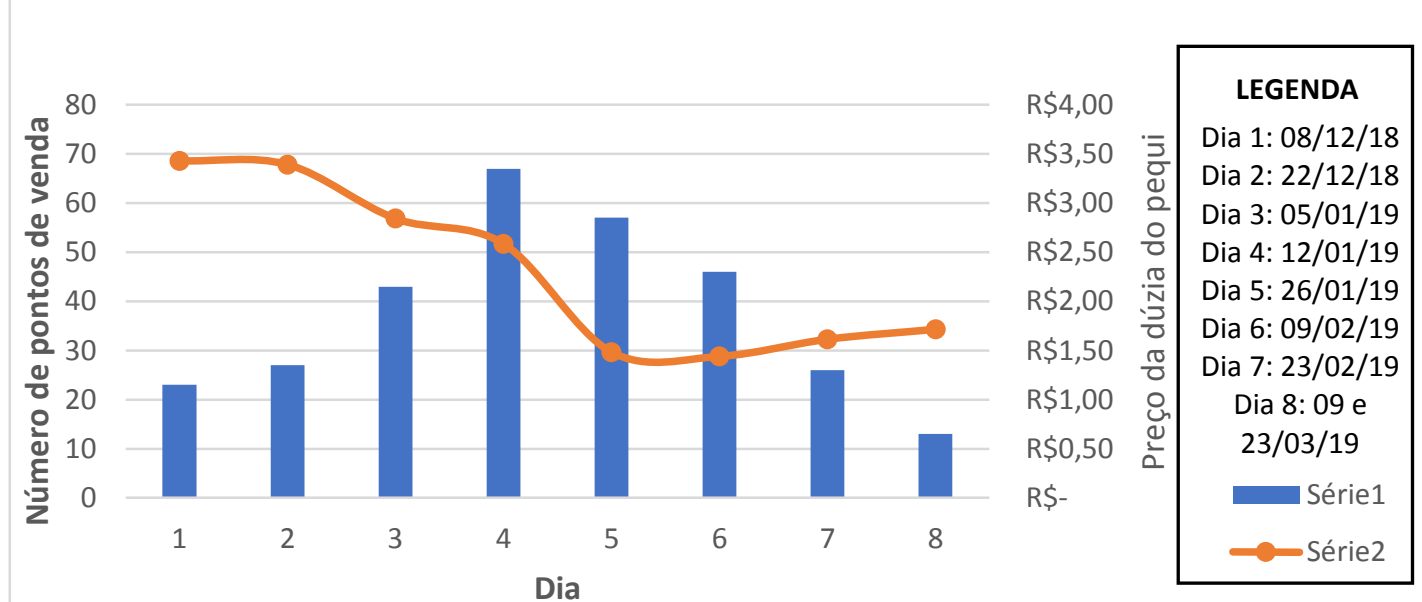

Fonte: Pesquisa de campo, 2018/2019. Organizada pelos autores, 2020.

Em começos de dezembro existem poucos pontos de venda do produto, mas é o período do maior preço da dúzia do pequi. Na entrada da safra o preço da unidade de venda, o "pacote", oscilou entre $\mathrm{R} \$ 5,00$ a $\mathrm{R} \$ 3,00$. "Pacote" é o termo adotado pelos atores da comercialização do pequi nas feiras livres, definindo assim as embalagens usadas para comercialização, em geral sacos plásticos transparentes. No dia 12 de janeiro de 2019, ápice da oferta, aconteceu a inflexão: à maior oferta se seguiu a maior queda de preços. 
No dia 26 de janeiro de 2019, ainda há alta oferta, a safra está no ponto máximo, o número de pontos de vendas se reduziu e o preço prosseguiu na tendência de baixa. Na passagem de janeiro para fevereiro o preço se estabilizou na baixa, com redução muito acentuada do número de pontos de vendas, o que contribuiu para manter o preço estável na queda, em torno de $\mathrm{R} \$ 1,72$.

Quando começa a safra, no mês de novembro, o pequi ofertado nas feiras do Alto Jequitinhonha vem de outros municípios: é o "pequi de fora”, como dizem os agricultoresfeirantes, trazido de municípios mais ao norte de Minas Gerais, quase sempre de Montes Claros ou Bocaiuva. Esse produto abastece as feiras livres das cidades analisadas neste artigo a partir de novembro, época em que se observa um curto período sazonal de intermediação comercial. A maioria dos feirantes do Alto Jequitinhonha vende produção própria: 92,55\% de acordo com Cruz (2019); no entanto, a partir de novembro alguns intermediários, geralmente pequenos comerciantes, antecipam a oferta do fruto na feira para ganhar com os preços mais elevados, aproveitando da safra precoce dos municípios ao norte. Estes intermediários, que atuam de novembro até no máximo janeiro, chegam a ocupar $8 \%$ do total dos pontos de vendas do pequi, e saem dos mercados quando se firma a safra municipal.

O Gráfico 3 acompanha esse movimento de intermediação, quantificando a participação do pequi "local” e "de fora" conforme a evolução da safra. É preciso ressalvar que os agricultores-feirantes consideraram a safra municipal de pequi de 2018/2019 muito reduzida em comparação com os anos anteriores; notaram que alguns pequizeiros sofreram com a queda de flores, e outros quase não produziram frutos. $\mathrm{O}$ gráfico também mostra a presença majoritária da oferta "de fora" em começos de dezembro, que perdura por duas semanas; na passagem de dezembro a janeiro e até meados de janeiro essa participação permanece elevada, mas já se torna inferior à oferta da produção local.

Percebe-se que o produto "de fora” só permanece expressivo em termos de pontos de venda até o pico de oferta, que no caso analisado aconteceu em 26 de janeiro. O início de janeiro de 2019, com a entrada da safra do município e o aumento do número de pontos de venda do produto, ocorreu redução de preço, e neste momento há retração gradual da oferta do vendedor do produto "de fora", que sai do mercado acompanhando a tendência 
A comercialização de produtos do agroextrativismo em feiras livres do Alto Jequitinhonha
Danilo Marinho Lamêgo Borges Vanessa Marzano Araújo

Eduardo Magalhães Ribeiro Maria Sirlene da Cruz Lucas Rocha Santos

de baixa de preços. Num município tem a saída controlada: na feira de Itamarandiba o pequi "de fora" só pode ser vendido enquanto não começa a safra do pequi local, em meados do mês de janeiro, para não retirar o direito de venda dos agricultores-feirantes do próprio município. O comportamento inverso entre oferta e preço determina, nos demais municípios, esse momento de saída do vendedor do produto "de fora", que deve bancar custos de compra e transporte para participar da feira livre, ao contrário do agricultor-feirante, que coleta o produto nos campos e chapadas comuns e o leva à feira junto com sua pauta costumeira de vendas; tem, portanto, custos inferiores, embora encontre também preços menores.

Gráfico 3 - Pontos de vendas do pequi nas feiras livres, discriminados por origem "de fora" e local no conjunto dos municípios pesquisados.

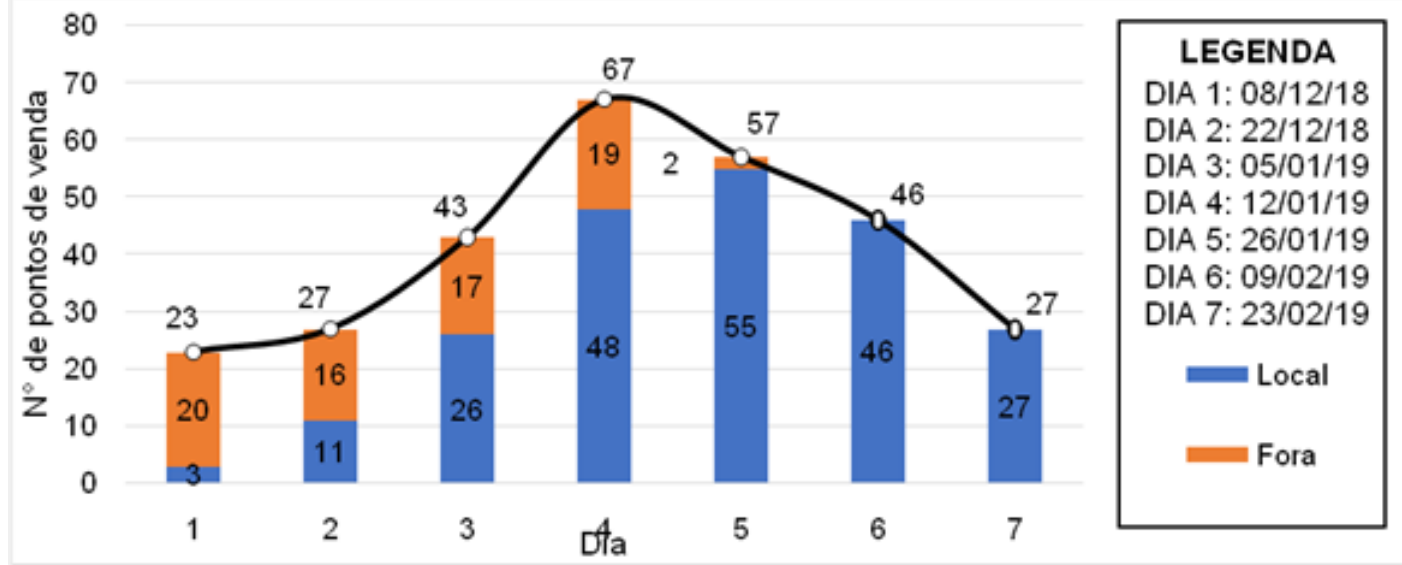

Fonte: Pesquisa de campo 2018/2019. Organizada pelos autores, 2020.

A presença expressiva do pequi "de fora" nas feiras livres de dezembro está associada ao ritmo diverso do amadurecimento do fruto, que vem principalmente da região de Montes Claros, norte de Minas Gerais. Considera-se que seu fruto tem caroços maiores, mais carnudos e cheirosos (POZO, 1997). O pequi originário desta região é responsável pela regulamentação da oferta e determinação de preço do produto no mercado do estado de Minas Gerais, inclusive nas feiras livres do Alto Jequitinhonha. Pozo estudou a comercialização do pequi na região de Montes Claros e estimou a variação do preço durante a safra. Relacionando os preços encontrados por Pozo (1997) com aqueles encontrados nas feiras livres do Alto Jequitinhonha, é possível analisar a variação 
histórica de preço, tomando como base de comparação o salário mínimo vigente no período das duas pesquisas. A comparação está apresentada no Quadro 2.

Quadro 2 - Preços históricos e corrigidos de pequi nas safras de 1997 e 2018/2019, no mercado de Montes Claros.

\begin{tabular}{|c|c|c|c|c|}
\hline Fonte & $\begin{array}{c}\text { Preço máximo } \\
\text { histórico }(\mathrm{R} \$)\end{array}$ & $\begin{array}{c}\text { Preço máximo } \\
\text { corrigido 2018 }(\mathrm{R} \$)\end{array}$ & $\begin{array}{c}\text { Preço mínimo } \\
\text { histórico }(\mathrm{R} \$)\end{array}$ & $\begin{array}{c}\text { Preço mínimo } \\
\text { corrigido 2018 }(\mathrm{R} \$)\end{array}$ \\
\hline Pozo & 4,00 & 14,22 & 0,50 & 1,77 \\
\hline Pesquisa de campo & 3,50 & 3,50 & 1,50 & 1,50 \\
\hline
\end{tabular}

Fonte: Pesquisa de campo, 2018/2019 e Pozo (1997); preços corrigidos pelo IPCA (IBGE). Organizada pelos autores, 2020.

Pelo Quadro 2 se percebe que o preço real máximo da dúzia do pequi teve queda entre 1997 e 2018: no período, o preço de 2018 chegou a um quarto do valor observado em 2017. Mesmo em termos nominais houve queda do preço máximo nos anos da comparação. O preço mínimo na safra permaneceu praticamente o mesmo, revelando que a diferença entre máximo e mínimo se reduziu no período da comparação. Essas diferenças indicam maior vigor da oferta do produto, que é resultado do maior volume nos mercados, de melhorias na logística, e de menores flutuações, que asseguram assim maior estabilidade dos preços. No entanto, a queda do preço máximo seguramente também indica queda histórica na receita do vendedor pioneiro, aquele que entra com os primeiros produtos nos mercados em dezembro. A maior estabilidade, ou menor flutuação, dos preços, certamente deve contribuir para planejamento mais apurado do intermediário e do agricultor-feirante.

\section{Considerações finais}

A comercialização de produtos da natureza por agricultores familiares do Alto Jequitinhonha passa por variações sazonais de oferta e de tipos de produtos, enfrenta limitações nas áreas de coleta, que em sua maioria foram monopolizadas por grandes empresas, e tem que superar os desafios do transporte, dos preços e se adequar ao gosto do consumidor.

Apesar dessas limitações, o agroextrativismo tem expressiva presença nas feiras livres dos municípios analisados no Alto Jequitinhonha, chegando a representar perto de $10 \%$ dos pontos de venda. Ocorre aqui uma junção virtuosa entre os recursos do Cerrado, a biodiversidade das áreas de transição de biomas, as preferências dos consumidores 
A comercialização de produtos do agroextrativismo em feiras livres do Alto Jequitinhonha
Danilo Marinho Lamêgo Borges Vanessa Marzano Araújo

Eduardo Magalhães Ribeiro Maria Sirlene da Cruz Lucas Rocha Santos

urbanos e a força da agricultora tradicional. $\mathrm{O}$ artigo revela que esta, principalmente, enfrenta notáveis desafios - secas, tomadas de terras, custos de transporte - para prover cidades de pequeno porte com um cardápio de bens de consumo de qualidade, adaptados aos costumes, com reduzidos ônus ecológicos. Neste particular, existem aspectos que merecem destaque: o reduzido consumo de água, a movimentação mínima de terras e o baixo gasto de energia na produção e no transporte desses produtos, que em sua maioria resultam do esforço puramente humano de coleta (ou "catação", como dizem os agricultores) e de viagens que raramente ultrapassam 20 quilômetros.

Detalhe muito relevante dessa produção também é a diversidade: 51 produtos, boa parte deles únicos, ofertados em apenas uma feira, registrando a singularidade dos circuitos curtos de comercialização, organizados quase que na medida exata necessária para atender à demanda exclusiva de "seus" consumidores. Vendem frutas nativas, plantas alimentícias não convencionais, plantas de uso medicinal e materiais para trabalho, ornamentação e lazer, reforçando a soberania alimentar e a cultura do Território do Alto Jequitinhonha. O canal curto garante a renda dos agroextrativistas-agricultoresfeirantes e a fidelização dos clientes, que conhecem a procedência e a qualidade dos produtos, e modulam seu consumo pela variação das safras.

A feira livre, por fim, é a vitrine onde são exibidos esses produtos, mas que exibe também, com muita força, a exuberância dessa cultura tradicional enraizada no território.

\section{Agradecimentos}

Os autores agradecem aos apoios do Conselho Nacional de Desenvolvimento Científico e Tecnológico (CNPq), da Fundação de Amparo à Pesquisa do Estado de Minas Gerais (FAPEMIG), do Núcleo de Pesquisa e Apoio à Agricultura Familiar (Núcleo PPJ/UFMG), do Centro de Agricultura Alternativa Vicente Nica (CAV), das associações de feirantes e prefeituras dos municípios pesquisados e, especialmente, dos feirantes que forneceram as informações analisadas neste artigo.

\section{Notas}

${ }^{1}$ No Alto Jequitinhonha são denominadas como "jacas" um conjunto de frutas com características semelhantes, como araticum, marolo, panã, fruta do conde, graviola, pinha, entre outras denominações populares. 
A comercialização de produtos do agroextrativismo em feiras livres do Alto Jequitinhonha
Danilo Marinho Lamêgo Borges Vanessa Marzano Araújo Eduardo Magalhães Ribeiro Maria Sirlene da Cruz Lucas Rocha Santos

\footnotetext{
${ }^{2} \mathrm{O}$ mercado municipal é uma edificação de propriedade pública, onde geralmente ocorre a feira livre, que às vezes admite uso múltiplo e abriga eventos de interesse público.
}

\section{REFERÊNCIAS}

ANDRADE, D. P. Ação coletiva de agroextrativistas em circuitos curtos de comercialização de produtos do Cerrado: estudo de caso em Pirenópolis - GO. 2016. Dissertação (Mestrado em Agronegócios) - Universidade de Brasília, Brasília/DF, 2016.

ARAUJO, A. M.; RIBEIRO, E. M. Feiras, feirantes e abastecimento: uma revisão da bibliografia brasileira sobre comercialização nas feiras livres. Estudos Sociedade e Agricultura, Rio de Janeiro/RJ, v. 26, n. 3, p. 561-583, 2018. Disponível em: <https://revistaesa.com/ojs/index.php/esa/article/view/1199>. Acesso em: 29 maio. 2019.

AVIDOS, M. F. D.; FERREIRA, L. T. Frutos dos Cerrados: preservação gera muitos frutos. Biotecnologia, Ciência \& Desenvolvimento, Brasília/DF, v. 3, n. 15, p. 36-41, 2000 .

AZEVEDO, E.A. Comida e costumes. In: RIBEIRO, E.M. Do engenho à mesa. Belo Horizonte, Editora UFMG, 2019. p. 41-51.

BARRERA, A. Nuevas realidades, nuevos paradigmas: la nueva revolución agrícola. COMUNIICA, [s. 1.], p. 10-21, 2011. Disponível em: <http://repiica.iica.int/DOCS/B2144E/B2144E.PDF>. Acesso em: 29 maio. 2019.

BISPO, T. W. Agroextrativismo no Vale do Rio Urucuia - Minas Gerais: formas de organização da produção e da distribuição. 2014. Dissertação (Mestrado em Agronegócios)- Universidade de Brasília, Brasília/DF, 2014.

BISPO, T. W.; DINIZ, J. D. de A. S. Agroextrativismo no Vale do rio Urucuia- MG: uma análise sobre pluriatividade e multifuncionalidade no Cerrado. Sustentabilidade em Debate, Brasília/DF, v. 5, n. 3, p. 37-55, 2014.

BRANDÃO, C. R. Saber de classe e educação popular. In: BRANDÃO, C. R. O ardil da ordem. Campinas: Papirus, 1986. p. 09-40.

BRASIL. MDA/SDT. Marco referencial para apoio ao desenvolvimento de territórios rurais. Série documentos institucionais 02-2005. Brasília: SDT, 2005.

BRASIL. Guia alimentar para a população brasileira. Brasília/DF: Ministério da Saúde, 2014.

BRASIL. INSTRUÇÃO NORMATIVA CONJUNTA No 18, DE 28 DE MAIO DE 2009, Que regulamenta o processamento, armazenamento e transporte de produtos orgânicos. Diário oficial da União, Brasília/DF, p. 31, 2009. 
A comercialização de produtos do agroextrativismo em feiras livres do Alto Jequitinhonha
Danilo Marinho Lamêgo Borges Vanessa Marzano Araújo Eduardo Magalhães Ribeiro Maria Sirlene da Cruz Lucas Rocha Santos

CALIXTO, J. S. A botica da natureza: coleta e processamento de plantas medicinais nas áreas de terras comuns do Alto Jequitinhonha. 2002. 67 f. Monografia (Graduação) - Engenharia Florestal, Departamento de Ciências florestais/UFLA, Lavras, 2002.

CANÊDO, N. S. Pequi, fruto da terra e dos saberes dos povos do cerrado: um olhar sobre a proteção dos direitos do conhecimento. 2014. Dissertação (Mestrado em Direito). Universidade Federal de Goiás, Goiânia/GO, 2014.

CARRARA, A. Reconversão agroextrativista: perspectivas e possibilidades para o Norte de Minas Gerais. 2007. Dissertação (Mestrado em Desenvolvimento SustentávelUniversidade de Brasília, Brasília/DF, 2007.

CRUZ, M. S. Da et al. Feiras livres: Comercialização da agricultura familiar e abastecimento urbano no Alto Jequitinhonha, Minas Gerais. In: CONGRESSO DA SOBER, 57. 2019a, Ilhéus/BA. Anais [...] Ilhéus/BA: Sociedade Brasileira de Economia, Administração e Sociologia Rural, 2019.

CRUZ, M. S. Da. Do campo para a cidade: estudo sobre feiras livres, abastecimento urbano e comercialização da agricultura familiar no Alto Jequitinhonha. 2019. Dissertação (Mestrado associado em Sociedade, Ambiente e Território) - ICAUFMG/Unimontes, Montes Claros/MG, 2019.

DAROLT, M. R.; LAMINE, C.; BRANDEMBURG, A. A diversidade dos circuitos curtos de alimentos ecológicos: ensinamentos do caso brasileiro e francês.

Agriculturas, Rio de Janeiro/RJ, v. 10, n. 2, p. 8-13, 2013.

DIABETÉ, I.; QUARANTA, N. Agricultura ética no combate à exploração e ao racismo. Agriculturas, Rio de Janeiro/RJ, v. 18, n. 2, p. 21-22, 2018.

DIAS, J. et al. Por normas sanitárias mais justas e inclusivas - em defesa da comida como patrimônio e da soberania e segurança alimentar e nutricional. Agriculturas, Rio de Janeiro/RJ, v. 14, n. 2, p. 33-39, 2018.

FOOD AND AGRICULTURE ORGANIZATION - FAO. O estado da segurança alimentar e nutricional no Brasil: um retrato multidimensional. Brasília/DF: FAO, 2014.

FUNDAÇÃO JOÃO PINHEIRO - FJP. Plano de Desenvolvimento para o Vale do Jequitinhonha - Volume 01: Estratégias e ações. Belo Horizonte/MG: Fundação João Pinheiro, 2017.

GALIZONI, F.M. et al. Mantimento, alimento, sustento. In: RIBEIRO, E.M. Do engenho à mesa. Belo Horizonte, Editora UFMG, 2019a. p. 81-103. 
A comercialização de produtos do agroextrativismo em feiras livres do Alto Jequitinhonha
Danilo Marinho Lamêgo Borges Vanessa Marzano Araújo Eduardo Magalhães Ribeiro Maria Sirlene da Cruz Lucas Rocha Santos

GALIZONI, F. M. et al. Relatório final: comunidade rurais e água na microbacia hidrográfica do rio Fanado, Turmalina, MG. Montes Claros, CNPq/CAV/UFMG/IFNM, setembro 2019 b.

GIL, A. C. Como Elaborar um projeto de pesquisa. São Paulo/SP: Atlas, 2002.

GRAZIANO, E. \& GRAZIANO NETO, F. As condições da reprodução camponesa no vale do Jequitinhonha. São Paulo: Perspectivas, 1983.

\section{IBGE. INSTITUTO BRASILEIRO DE GEOGAFIA E ESTATÍSTICA. Censo}

Demográfico: Tabela 1378 - População residente, por situação do domicílio, sexo e idade, segundo a condição no domicílio e compartilhamento da responsabilidade pelo domicílio, 2010. Disponível em: 〈https://sidra.ibge.gov.br/Tabela/1378>. Acesso em: 17 mar. 2019.

. Malha Municipal. Disponível em: <

https://www.ibge.gov.br/geociencias/organizacao-do-territorio/15774malhas.html?=\&t=downloads $>$. Acesso em: 04 jun. 2020.

KIM, H. J. O conhecimento das mulheres como raiz da soberania alimentar na Coreia do Sul. Agriculturas, Rio de Janeiro/RJ, v. 14, n. 2, p. 11-15, 2018.

LOPES, P. S. N. et al. Pequi. In: VIEIRA, R.B. et al. Frutas Nativas da Região Centro-Oeste do Brasil..Brasília/DF: Embrapa Recursos Genéticos e Biotecnologia, 2006. p. 248-289.

MALINOVSKY, B. \& DE LA FUENTE, J. La economia de un sistema de mercados en México. México DF, Acta Anthropologica, v. 1, n. 2, 1957.

MALUF, R. S. Produção, partilha e consumo de alimento em defesa da soberania e segurança alimentar e nutricional. Agriculturas, Rio de Janeiro/RJ, v. 14, n. 2, p. 4-6, 2018.

MARTINEZ, S. A nutrição e a alimentação como pilares dos programas de promoção da saúde e qualidade de vida nas organizações. Mundo da Saúde, São Paulo/SP, v. 37, n. 2, p. 201-207, 2013.

MELO, S. W. C. Extrativismo vegetal como estratégia de desenvolvimento rural no Cerrado. 2013. Dissertação (Mestrado em Agronegócios) - Universidade de Brasília, Brasília/DF, 2013.

MUSSOI, M. R.; ANJOS, M. de C. R. Dos. Entre produzir e reproduzir a vida: O cultivo do feijão preto graúdo por uma guardiã de sementes crioulas. Agriculturas, Rio de Janeiro/RJ, v. 14, n. 2, p. 7-11, 2018. 
A comercialização de produtos do agroextrativismo em feiras livres do Alto Jequitinhonha
Danilo Marinho Lamêgo Borges Vanessa Marzano Araújo Eduardo Magalhães Ribeiro Maria Sirlene da Cruz Lucas Rocha Santos

OLIVEIRA, W. L. De. Boas práticas de manejo para o extrativismo sustentável do pequi. Brasília/DF: Embrapa Recursos Genéticos e Biotecnologia, 2010.

POZO, O. V. C. O pequi (Caryocar brasiliense): uma alternativa para o desenvolvimento sustentável do cerrado no Norte de Minas Gerais. 1997. Dissertação (Mestrado em Administração Rural) - Universidade Federal de Lavras, Lavras/MG, 1997.

RIBEIRO, E. M. Feiras do Jequitinhonha: mercados, cultura e trabalho de famílias rurais no semi-árido de Minas Gerais. Fortaleza/CE: Banco do Nordeste do Brasil, 2007.

RIBEIRO, E. M.; GALIZONI, F. M. Terra, lavoura e migração no Alto Jequitinhonha. In: RIBEIRO, E. M. Sete estudos sobre a agricultura familiar do Vale do Jequitinhonha. Porto Alegre/RS: Editora da UFRGS, 2013. p. 25-44.

RIBEIRO, E. M. (org.) Sete estudos sobre a agricultura familiar do Jequitinhonha. Porto Alegre. Editora da UFRGS, 2013.

SAINT-HILAIRE, A.de. Viagem pelas províncias do Rio de Janeiro e Minas Gerais. Belo Horizonte/Itatiaia; São Paulo/Edusp, 1975.

SERVILHA, M. de M. As relações de trocas materiais e simbólicas no mercado de Araçuaí - MG. 2008. Dissertação (Mestrado em Extensão Rural) - Universidade Federal de Viçosa, Viçosa/MG, 2008.

SILVA, C. E. M. O Cerrado em Disputa: apropriação global e resistências locais. Brasília/DF: Confea, 2009.

SILVA, F.L.. Comida e sustância. In: RIBEIRO, E.M. Do engenho à mesa. Belo Horizonte, Editora UFMG, 2019. p. 69-79.

SOUZA, J.A.G. Comida e agricultura. In: RIBEIRO, E.M. Do engenho à mesa. Belo Horizonte, Editora UFMG, 2019. p. 61-67.

YIN, R. K. Estudo de caso: planejamento e métodos. 2. ed. Porto Alegre/RS:

Bookman, 2001. 